\title{
THE HEADMASTER'S STRATEGIES IN IMPLEMENTING MANAGEMENT BASED ON SCHOOLS IN SMP MUHAMMADIYAH 4 GEMPOL, PASURUAN
}

\author{
Saiful Hadi \\ email saiful_hadi2010@yahoo.co.id
}

\begin{abstract}
This study aims to find out and explore how does the headmaster implement it? what is the obstacle facing him? what strategy is done? This research uses four approaches that are pedagogies, sociological, juridical and psychological. The sources of the data are primary and secondary. The instruments are interviews, observation guides, check list observation, and documentation. The research techniques are data reduction techniques, data presentation, and conclusions. From the results of the research of school-based management in SMP Muhammadiyah 4 Gempol, it can be concluded: The headmaster has implemented school-based management but the implementation has not fully implement school-based management. The headmaster as a leader using School Based Management still needs improvement and improvement of teacher quality and good cooperation with school partners. Constraints faced a) Lack of educational facilities and infrastructure b) lack of teacher competency c) lack of parental support of learning process, d) lack of intensive and maximal socialization, e) lack of master of technology. Strategies undertaken in implementing school-based management ie a) doing relationship with relevant agencies to provide the facilities and the infrastructure b) improving teacher competence by involving teachers in trainings c) doing relationship with parents to improve the quality of education. The implications of this research is expected for the headmasters and teachers to always perform their duties and functions respectively each other. To the teachers of SMP Muhammadiyah $4 \mathrm{Gempol}$, to always strive to improve the professionalism of work for the quality of school education in particular and in general can be better. To the relevant agencies would pay attention to the development of each school.
\end{abstract}

Keywords: Strategy, Leadership, Management

\section{A. Introduction}

In a living society that still needs revamping as today, where the country is experiencing a prolonged multidimensional crisis, both in economic, political and social, all of which is actually sourced from low quality, ability and spirit of working. From this, it can be said that the nation cannot independently and too much rely on intervention from foreign parties. Although the reform agenda has been fought for and perpetuated in order to improve this multidimensional crisis, it does not take place completely.

In addition, the real reforms inherent in their strength lie in qualified Human Resources (HR), and have vision, transparency, and foresight that are not only selfish and group, but always prioritize the interests of the nation and state in various social life. One of the vehicles to improve the quality of human resources is education, so the quality of education should always be improved. Education is a critical determinant of the success of development, where the quality of human resources is enhanced through various educational programs implemented systematically and directed based on interests that refer to 
the progress of science and technology and based on faith and piety. ${ }^{1}$

Education in Indonesia is still low quality. This is marked by the frequent brawl between students in various cities coupled with a number of their behavior that leads to criminal, drug abuse continues to increase, and promiscuity among adolescents. This is evidence that education in this country is not successful in forming learners who have an Islamic personality. If the world of education is not immediately addressed quickly and accurately, it is not impossible that this sector will be abandoned by the times. That way, there needs to be awareness to showcase qualified educational institutions in an effort to solve and respond to new challenges that arise in every age. ${ }^{2}$

This is similar to what is stated by Hari Suderajat that, the quality of education Indonesia is in a low position. It demands all educational institutions in this country to rise and fight in an effort to improve education to become a quality institution and can be proud to Indonesian. ${ }^{3}$

Various efforts have been made to improve the quality of national education, among others through various trainings and improvements in teacher competence, procurement of books and instructional tools, improvement of education facilities and infrastructure and improvement of

\footnotetext{
${ }^{1}$ E. Mulyasa, Manajemen Berbasis Sekolah (Cet. VII; Bandung: Remaja Rosdakarya 2004).

${ }^{2}$ Abuddin Nata, Manajemen Pendidikan: Mengatasi Kelemahan Pendidikan di Indonesia (Bogor : Kencana, 2003).

${ }^{3}$ Hari Suderajat, Sebuah Pengantar: Pendidikan Berbasis Luas (BEE) yang berorientasi pada kecakapan hidup (Life Skill) (Cet. III; Bandung: Cipta Cekas Grafika, 2003).
}

school management quality. However, various indicators of educational quality have not shown significant improvement.

One alternative form of educational change is School Based Management or School-Based Management (SBM). ${ }^{4}$ Through this concept there is a demand to give wider authority to schools to manage and empower all existing educational resources within the school and community environment. School empowerment with all staffs is at the core of School-based Management. ${ }^{5}$

School-based management is a new paradigm of education, which provides widespread autonomy at the school level (community engagement) within the framework of national education policy. Autonomy is given to schools to freely manage resources and resources by allocating them according to their need priority, and more responsive to local needs. People involvement is intended to make them more understand, help and control of education management. In the meantime, the national policy which is the government's priority should also be done by the school. In the MBS system, schools are required to independently explore, allocate, prioritize, control and account for the empowerment of resources, both to the public and the government. ${ }^{6}$

\footnotetext{
${ }^{4}$ School based management can be translated as a model of management that give an autonomy (authority and responsibility which is bigger to the headmaster). Look at Rohiat, managemen sekolah teoro dasar dan praktik (cet II; Bandung: Refika Aditama, 2009)

${ }^{5}$ Sudarwan Denim, Visi Baru manajemen Sekolah dari Unit Birokrasi Ke Lembaga Akademik (Cet II; Jakarta: PT Bumi Aksara, 2007)

${ }^{6}$ E. Mulyasa, Manajemen Berbasis Sekolah
} 
School-based management is a management concept that begins with the school's ability, initiative and creativity in conducting education at its school, which is independent of 'top' instructions. All decision-making activities, planning, and policies for the administration of education come entirely from the school's own initiative, not the layers of the bureaucracy on it.

School-based management is seen as an approach to school management in the context of decentralized education that gives wider schools the authority to make decisions about the management of school education resources supported by the high participation of citizens, parents and communities in accordance with the policy framework national education in order to improve the quality of education.

The issuance of Law No. 20 of 2003 on National Education System verse 51 point 1 which mandates that: Management of kindergarten education units, basic education, and secondary education implemented based on minimum service standards with the principle of school-based management. ${ }^{7}$

While in Government Regulation on Management Standard Chapter VIII section I verse 49 point 1 , it is explained that: Management of educational unit at primary and secondary education level implements school-based management as indicated by independence, partnership, openminded and accountability. ${ }^{8}$

The Laws and Regulations of the Government are, in essence, a vehicle for the effort to establish a

\footnotetext{
${ }^{7}$ Republik Indonesia, Undang-Undang RI Nomor 20 tahun 2003 Tentang Sistem Pendidikan Nasional (Cet. II; Jakarta: Sinar Grafika Offset, 2009)
}

school community and take care of its own household. So that they are in decision making which covers the life of the school community or stakeholders, actively involved.

The role of the headmasters in improving school-based management is expected especially in SMP Muhammadiyah 4 Gempol, Pasuruan. All will have an impact in terms of planning, learning and evaluation process. If the headmaster is not able to manage in the school then it will not run effectively and efficiently. The headmaster of SMP Muhammadiyah 4 Gempol, Pasuruan, must run schoolbased management programs.

Thus, school-based management should be conducted as well as possible to see the headmaster should have the headmaster's competence and skills in performing the task as the headmaster, especially in SMP Muhammadiyah 4 Gempol, Pasuruan. So, from this the author will examine the headmaster's strategy so that in developing the school can run well.

The success of School-based Management depends on the headmaster who is able to manage the school well. Therefore, school-based management is the authority of schools to develop school programs in accordance with the desired needs. Therefore, the authors take the title "The Headmaster's Strategies in implementing School Based Management in SMP Muhammadiyah 4 Gempol, Pasuruan".

\section{B. Research Methods}

This research is a descriptive qualitative research that collects

\footnotetext{
${ }^{8}$ Republik Indonesia, Peraturan Pemerintah Republik Indonesia Nomor 19 tahun 2005 Tentang Standar nasional Pendidikan (Cet.III; Jakarta: Sinar Grafika, 2007), h. 28
} 
information about the status of an existing symptom and describes the situation according to "what is" about a variable, symptom or circumstance. ${ }^{9}$ Descriptive research is intended for exploration and clarification of a phenomenon or social reality, by way of describing a number of variables concerning the problem and the unit that is researched. ${ }^{10}$ This research is used to describe and analyze the headmaster's strategy in implementing school based management in SMP Muhammadiyah 4 Gempol, Pasuruan.

This research was conducted in SMP Muhammadiyah 4 Gempol, Pasuruan Regency, East Java Province. There are three important elements that I consider in determining the location of the study. They are place, actors, and activities. Researchers chose the location of this study, because that school is an interesting school to do a development and the researcher is interested especially in the field of management of the headmaster's strategy.

This research uses a kind of multidisciplinary approach that is pedagogical approach. This approach is done to obtain data by examining the opinions or thoughts of educational practitioners related to the research that the author thoroughly; The juridical approach. This approach was undertaken to understand the Law of the Republic of Indonesia Number 20 Year 2003 on the National Education System, Government Regulation of the Republic of Indonesia Number 19 Year 2005 on National Education Standards

\footnotetext{
${ }^{9}$ Suharsimi Arikunto, Manajemen Penelitian (Cet. IV; Jakarta: Rineka Cipta, 1998)

${ }^{10}$ Ibnu Hadjar, Dasar-Dasar Metodologi penelitian Kwantitatif Dalam Pendidikan( Cet. II; Jakarta: Raja Grafindo Persada, 1999

${ }^{11}$ Documentation method finds thye data of the reseach through knowing the things or variable
}

and other command policies relating to this research; Sociological approach. This approach is used because researchers in collecting data will enter a social environment with a set of binding rules, in addition researchers will also interact with other individuals; The psychological approach, namely the approach used to study the symptoms, the human behavior to be observed in the school environment.

The data in this study comes from government policies, books, and reading materials in accordance with the discussion of school-based management in SMP Muhammadiyah 4 Gempol, Pasuruan. The data sources are divided into two, namely primary data and secondary data.

Primary data in field research is the main data taken directly from the location of research that comes from the informants, namely: the headmasters, teachers 14 people, school committee 1 person, administration 1 person. So, the total number of informants is 16 people; Secondary data are supporting data obtained from literature such as books, magazines, and other sources deemed relevant to the research objectives. The data is termed with documentation. ${ }^{11}$ Reports of the implementation of management activities undertaken by the educational unit is a source of high enough units.

Data collection techniques in this study include observation / observation, interview / interview and documentation. Observation is a direct

which is on a note, transcrip, book, magz, newspapper, relieve, meeting notation, lengger, agenda, and so on. Look at Suharsimi Arikunto, Prosedur Penelitian, suatupendekatan Praktis (Jakarta: Rineka Cipta, 1991) 
observation of the object under study to know the existence of the object, situation, context and meaning in the effort to collect research data. ${ }^{12}$ The researchers conducted direct observation at the research site to see directly the object of research, the researcher observed and recorded or collected data by using direct and indirect observation guidance in the research location of strategy conducted by the headmaster in implementing school-based management in SMP Muhammadiyah 4 Gempol, Pasuruan.

The interviews consist of two types, namely structured interviews and unstructured interviews. Structured interviews that have been pre-defined in the questionnaire with the options provided. Unstructured interviews are usually called in-depth interviews and open interviews. ${ }^{13}$ This study uses unstructured interviews or in-depth interviews with data sources, to get informants about the headmaster's strategy in implementing school-based management at SMP Muhammadiyah 4 Gempol, Pasuruan.

Researcher's documentation obtains information from supporting data in the form of written sources or documents related to the object of research, such as the history of the establishment of the school, list of names of headmasters who had served, teacher's data, and other records. This method is used to find the data variable that can be used as information complement the research data.

The data obtained from the researchers will be analyzed in order to obtain valid data to be presented in

\footnotetext{
12 Djam'an Satori, dkk. Metodologi Penelitian Kuantitatif (Cet. I; Bandung: Alfabeta, 2009)

${ }^{13}$ Lihat Deddy Mulyana, Metode Penelitian Kualitatif: Paradigma Baru Komunikasi dan Ilmu Sosial Lainnya (Cet. IV; Bandung: Remaja Rosdakarya, 2008)
}

accordance with the issues discussed. In this study the authors use three stages in performing data analysis, namely:

Reduction of the data, all data in field are analyzed at once summarized, selected things that are central and focused on the main issues that are considered important, sought the theme and pattern so arranged in a systematic and easy to understand. ${ }^{14}$ Reduced data is then presented in the form of a research report so that the description of the research results will be clearer.

Presentation of data, in the presentation of this data the authors present the results of research, how the new findings are associated with previous researchers. Data presentation in the research aims to communicate interesting things from the problems studied, the method used, the findings obtained, the interpretation of results, and its integration with theory.

Withdrawing conclusions, at this stage the authors make conclusions of what is drawn and suggestions as the end of the research. The next process in this study is, data analysis aimed to simplify the data collected so as to enable researchers to explain it. The type of analysis used is the type of data that is qualitative, I.e. in the described with words or sentences are separated by category to obtain conclusions. ${ }^{15}$

\section{Results and Discussion}

The headmaster who is the leader in this case needs to understand the body of management, so the school is managed to meet the expectations of the community. Therefore, the

\footnotetext{
${ }^{14}$ Sugiyono, Metode Penelitian Pendidikan Pendekatan Kuantitatif, Kualitatif, dan R\&D (Cet.VI; Bandung: Alfabeta, 2008)

${ }^{15}$ Husain Usman dan Purnomo Setiady Akbar, Metodologi Penelitian Sosial (Jakarta: Bumi Aksara, 2009)
} 
headmaster's professionalism to implement school-based management through leadership and communication support will create good school management. Without a good school management of the achievement of common goals will be difficult to be realized with the maximum.

The concept of school-based management refers to resource management at the school level that involves community participation, school citizens, parents, and the community. These resources include: power, knowledge, technology, finance, human, material and time.

Through the MBS schools can have more control in directing the organization of the school in the future, in accordance with the goals and strategies set by the school. Besides, the school also has control over finance and improvement of learning process also to curriculum development, and how to use material in learning process.

Essentially the implementation of school-based management is to improve the quality and relevance of education, both concerning the quality of learning, the implementation of the curriculum, the utilization of learning resources, human resources and other education personnel, and educational services.

About school-based management is contained in Law no. 20 of 2003 on National Education System article 1 , verse 1 , states that the management of kindergarten education units, primary education and secondary education are implemented based on minimum service standards with the principle of school-based management.

Furthermore, the goal of implementing school-based management leads to more schooling (autonomy or self-reliance) in managing resources that are owned effectively and efficiently, and encourages schools to make informed, participatory, transparent and accountable decision-making in achieving predetermined objectives. The implementation of school-based management provides a great responsibility in the management of education and learning in schools, in accordance with the conditions of each school.

Autonomy of education management is the implementation of the national education strategy contained in point 10 of the general explanation of Law No. 20 of 2003 on National Education System which is part of the vision and mission. ${ }^{16}$ Therefore, vision and mission of education unit of SMP Muhammadiyah 4 Gempol, namely: Vision; be pious, excellent in Achievement, and cultured.

Being pious is a school that always maintains faith that is realized in the experience of Islamic teachings as a whole. Superior in achievement that is becoming a quality school in science both academic and nonacademic. Being cultured is to be a man who behaves well, morally, courtesy to a neighbor or God created creature.

Mission is the means to realize the vision. The mission of SMP Muhammadiyah 4 Gempol is the aspirations of the headmasters, vice the headmasters, teachers, education personnel, and other school communities that will serve as a fundamental element of school programming in school view, with clear and consistent reasons for school values. The mission of SMP Muhammadiyah 4 Gempol is a real

\footnotetext{
${ }^{16}$ UU RI Nomor 20 Tahun 2003.
} 
action that needs to be done to achieve school goals and all school citizens participate in synergy in accordance with their respective duties.

The implementation of schoolbased management in SMP Muhammadiyah 4 Gempol has benefits, especially in the case of: (1) allowing competent people in school to make decisions that will improve learning; (2) Providing an opportunity for the schoolchild (Educators, staff, parents and community) in their decision-making; (3) Focusing accountability on decisions; (4) leads to greater creativity and flexibility in designing programs so as to meet the needs of learners; (5) encouraging parents and learners to be aware of the financial status of the school; (6) improving the quantity, quality, and flexibility of communication among the school community.

The implementation of schoolbased management is related to the standard of management by the educational unit listed in PP RI Number 19 Year 2005 on National Education Standards article 49 paragraph 1, namely the management of educational units at elementary and secondary education level applying school-based management as indicated by independence, openness, and accountability.

Explain that the management of educational units includes program planning, curriculum compilation of educational unit level, learning activities, utilization of educators and education personnel, management of education facilities and infrastructure, assessment of learning outcomes and supervision.

Implementation of school-
based management at SMP
Muhammadiyah 4 Gempol, can be
known based on the results of research

conducted by researchers that indicated by the independence, partnership, participation, openness and accountability.

Independence can be known by the results of interviews with educators at SMP Muhammadiyah 4 Gempol in organizing and manage school independently through the management of school programs in SMP Muhammadiyah 4 Gempol. Partnership is a colleague between SMP Muhammadiyah 4 Gempol and the school committee in facilitating the quality of learning services. Participation involving directly the school and community residents in the implementation of education at SMP Muhammadiyah 4 Gempol in the implementation of school programs and assistance related to finance for the development of facilities and infrastructure SMP Muhammadiyah 4 Gempol.

Openness / transparency is openness in programs and finances that are managed in SMP Muhammadiyah 4 Gempol. Based on the results of the research at the meetings between the parents of the learners the school accounted for reports relating to financial, educators, graduate competence, or the quality and performance achieved by the school. The accountability applied by SMP Muhammadiyah 4 Gempol is to provide information, explanation, accountability of work to various parties concerned or to education stakeholders (parents, learners, community, observers of education) through reporting or meeting openly.

Management of educational units implementing school-based management in SMP Muhammadiyah 4 Gempol Includes: Program planning, curriculum compilation of educational unit level, learning activities, 
utilization of educators and education personnel, management of educational facilities and infrastructure, assessment of learning outcomes, and supervision. Based on the results of research conducted, has been implemented in stages in accordance with existing procedures but not fully implemented in accordance with what was programed, such as utilization of educators and educational personnel, there are some teachers who have not mastered computer technology. This needs to be followed up.

The concept of school-based management is the idea that places the authority of school management in a system to make decisions. Each school certainly has its trademark, potential and constraints. As the results of research conducted by researchers at SMP Muhammadiyah 4 Gempol, the researcher concluded the obstacles faced by school the headmasters in implementing school-based management in SMP Muhammadiyah 4 Gempol namely: lack of socialization of school-based management, lack of support from parents of learners, lack of teacher competence, limited facilities and infrastructure, unevenly obtaining parents of learners.

Implementation of schoolbased management should pay attention to its characteristics, both seen from the aspects of input processes and outputs. Understanding of school-based management principles and characteristics will bring schools to better implementation of school-based management.

According to Slamet P.H. quoted Mohammad Syaifuddin said that the implementation of schoolbased management is a process that takes place continuously and involves all elements responsible for the implementation of school education.
Therefore, the headmaster's strategy should be implemented in implementing school-based management in SMP Muhammadiyah 4 Gempol as follows: Socializing the concept of school-based management. Socialization is done to all citizens of SMP Muhammadiyah 4 Gempol namely educators, education personnel, learners, parents learners, community, community leaders. Then the headmaster needs to hold a meeting with the parents of learners about the importance of children's education.

Furthermore, the headmaster chooses the steps to solve the problem such as the limited capacity of learners in the form of facilities and infrastructure to overcome this problem the headmaster SMP Muhammadiyah 4 Gempol Has worked with the Education Office to increase school facilities and infrastructure. The lack of teacher competence is that the headmasters include teachers for training such as computer training or seminars.

Next create a program plan and realize the plan of the program, such as cross-subsidizing as a form of justice in the implementation of education in SMP Muhammadiyah 4 Gempol. Based on the results of the research it can be seen that: Implementation of school-based management in SMP Muhammadiyah 4 Gempol not yet done well, therefore the improvement effort to be done well, has done the headmaster SMP Muhammadiyah 4 Gempol assisted by educators, education personnel and participation from (1) school independence, (2) school partnerships, (3) participation of the community, (4) accountability of openness from the school, (5) accountability that can be justified by school; Implementation of schoolbased management in SMP 
Muhammadiyah 4 Gempol greatly influence in improving the quality of education. The benefits of schoolbased management in SMP Muhammadiyah 4 Gempol can be seen from the increasing achievement of learners. The success of SMP Muhammadiyah 4 Gempol is certainly supported by the leadership of the headmaster who has a clear vision, mission and purpose and cooperation between educators, parents and the community; Management of educational unit includes program planning, arrangement of education unit level, learning activity, utilization of educator and educational staff, management of educational facilities and infrastructure, assessment of learning result, and supervision to improve the quality of education quality in SMP Muhammadiyah 4 Gempol not done well yet schools continue to look for ways to improve the management of education units in SMP Muhammadiyah 4 Gempol.

\section{Conclusions}

From the description that researchers have described, then there are some conclusions that can be taken as an answer to the problems that have been formulated, including:

1. Objective conditions of implementation of school-based management in SMP Muhammadiyah 4 Gempol, Pasuruan namely the headmaster SMP Muhammadiyah 4 Gempol already implement school-based management but in the implementation not yet maximal from School Based Management. Implementation of his duties as a leader to succeed SMP Muhammadiyah 4 Gempol as an educational institution still needs improvement and improvement of quality of teachers, and school residents and expected to be a good educational institution in terms of implementation of teaching and learning process as well as conducive in the implementation of daily work system.

2. Constraints faced by school the headmasters in implementing school-based management in SMP Muhammadiyah 4 Gempol, Pasuruan. a) Lack of educational facilities and infrastructure) Lack of teacher competence b) Limited human resources who master the technology, has not implemented cross-subsidy for the justice of education.

3. The strategy the headmaster undertakes in implementing school-based management in SMP Muhammadiyah 4 Gempol, Pasuruan, namely a) to improve the Teacher and Employee Competencies, the headmaster as a leader in the school includes teachers in trainings, b) to overcome the limitations of facilities and infrastructure, the headmaster cooperates with relevant institutions, and observers of education in improving the quality of education.

\section{References}

Arikunto, Suharsimi. Manajemen Pendidikan Cet. IV; Jakarta: RinekaCipta, 2000

Bank Dunia, Q/A for the web/knowledge nugget, ditulisoleh edge, 2000

Deddy Mulyana, Metode Penelitian Kualitatif: Paradigma Baru Komunikas idan Ilmu Sosial Lainnya, Cet. IV; Bandung: RemajaRosdakarya, 2008

Daryanto, Administrasi

Pendidikan,Jakarta:

RinekaCipta, 2007 
De Grauwedan Varghese dalam Hadiyanto, Mencari Sosok Desentralisasi Manajemen Pendidikan di Indonesia Cet. I; Jakarta: RinekaCipta, 2004

Denim, Sudarwan. Visi Baru manajemen Sekolah dari Unit Birokrasi KeLembaga Akademik Cet. II; Jakarta: PT BumiAksara, 2002

Departemen Agama RI, Al-Qur'an dan

Terjemahnya, Semarang: Toha Putra, 2002

Departemen Pendidikan Nasional, Kamus Besar Bahasa Indonesia, Edisi III; Cet.IV; Jakarta: Balai Pustaka, 2005.

Dekdikbud, Penugasan Guru Pegawai Negeri Sipil Sebagai Kepala Sekolah di Lingkungan Departemen Pendidikandan Kebudayaan,Jakarta: Dirjen Dikdasmen, 1999

Djati, SidiIndra. Kebijakan Penyelenggaraan Pendidikan Otonomi Daerah Bidang Pendidikan Bandung: PPs UPI, 2000

Fadjar, Malik A. Kata Pengantar dalam Ibistam Abu-Duhou, School Based Management, Cet. I; Logos, 2002

Fattah, Nanang. Konsep Manajemen Berbasis Sekolah dan Dewan Sekolah, Bandung: Pustaka Bani Quraisy, 2003.

Fasli Jalandan Dedi Supriadi, Reformasi Pendidikan dalam Konteks Otonomi Daerah ,Yogyakarta: Adicita Nusa, 2001

Hadjar, Ibnu. Dasar-Dasar Metodologi penelitianKwantitatif Dalam Pendidikan Cet. II; Jakarta: Raja GrafindoPersada, 1999

Handoko,Hani. Manajemen, Edisi 2, Yoyakarta: BPFE, 1999

Hasbullah, Dasar-dasar Ilmu Pendidikan, Cet. II; Jakarta: Raja Grafindo Persada, 2001
http::/anwarholil.blogspot.com./Peran Kepala Sekolah dalam Mengefektifkan Organisasi Sekolah/ 10 Juli 2013

Husain Usman dan Purnomo Setiady Akbar, Metodologi Penelitian Sosial Jakarta: Bumi Aksara, 2009

Irawan, Ade dkk. Mendagangkan Sekolah (Studi Kebijakan Manajaemen Sekolah, Jakarta: ICW, 2000

Lazaruth, Administrasi Pendidikan,Jakarta: RinekaCipta, 1999

Made, Wena. Strategi Pembelajaran Inovatif Kontemporer; Suatu Tinjauan Konseptual Operasional, Cet. II; Jakarta: Bumi Aksara, 2009.

Moleong, J.Lexy. Metodologi Penelitian Kualitatif. Cet. XXV; Bandung: Remaja Rosdakarya, 2008

Mulyana, Deddy. Metode Penelitian Kualitatif: Paradigma Baru Komunikasi dan Ilmu Sosial Lainnya, Cet, IV; Bandung: Remaja Rosdakarya, 2008

Mulyasa, Manajemen Berbasis Sekolah, Cet. VII; Bandung: Remaja Rosdakarya, 2004.

Manajemen Berbasis Sekolah Bandung: Rosdakarya, 2003

$$
\text { Menjadi Kepala }
$$

SekolahProfesional. Dalam Konteks Menyukseskan MBS dan $K B K \quad$ (Bandung: Remaja Rosdakarya, 2005), h. 182.

Nata, Abuddin. Manajemen Pendidikan: Mengatasi Kelemahan Pendidikan di Indonesia, Bogor :Kencana, 2003.

Nasution, S. Metode Penelitian Naturalistik Kualitatif, Bandung, Therisito, 2003. 
Sosiologi Pendidikan, Cet. I; Jakarta: Bumi Aksara, 1995.

Nawawi

Hadari.

AdministrasiPendidikan Jakarta: Mas Agung, 1989

Nurkholis, Manajemen Berbasis Sekolah, Cet. IV; Jakarta: Grasindo, 2008

Purwanto Ngalim, M. Administrasi Pendidikan Cet. XI; Jakarta: Mutiara Sumber Widya, 1986

Republik Indonesia No. 20 tahun 2003 tentang Sistem Pendidikan Nasional , Bandung : Fermana, 2006.

Republik Indonesia Peraturan Pemerintah Republik Indonesia Nomor 19 Tahun2005 Tentang Standar Nasional Pendidikan, Jakarta: Sinar Grafika, 2007

Rohati ,Manajemen Sekolah,Cet,I; Bandung: Refika Aditama,2008.

Rahman Tanjung, Arif. "Kepemimpinan Kepala Sekolah dalam Penerapan dalam manajemen Berbasis Sekolah pada SMA Gunung Sindur Bogor, Skripsi, Jakarta: UIN syarif Hidayatullah, 2006

Rusman. Manajemen Kurikulum, Cet. I ; Jakarta: Rajawali Pers, 2009

Sagala,Syaiful. Manajemen Berbasis Sekolah \& Masyarakat; Strategi Memenangkan Persaingan Mutu, Cet. I; Jakarta: Nimas Multimas, 2004

Satori, Djam'an dkk.

Metodologi Penelitian

Kuantitatif, Cet, Bandung: Alfabeta, 2009.

Sudrajat, Hari. Sebuah Pengantar: Pendidikan Berbasis Luas (BEE) yang berorientasi pada kecakapan hidup (Life Skill) Cet. III; Bandung: Cipta Cekas Grafika, 2003.

Sudjanto, Bedjo. Mensiasati manajemen Berbasis Sekolah di Era Krisis yang Berkepamjangan, Jakarta: ICW, 2004

Supriono S dan Achmad Sapari, Manajemen Berbasis Sekolah: Upaya Peningkatan Pendidikan Dasar Melalui Pemberdayaan Masyarakat Otonomi Sekolah Dan Pembelajaran Aktif, Kreatif, dan Menyenagkan (PAKEM) Cet. I: SSIC, 2001

Syaifuddin, Mohammad dkk. Manajemen Berbasis Sekolah, Bahan Ajar Cetak, Jakarta: Departemen Pendidikan Nasional, 2007.

Syafaruddin, Manajemen Lembaga Pendidikan Islam, Cet. I; Jakarta: Ciputat Press, 2005

Sugiyono, Metode Penelitian Pendidikan Pendekatan Kuantitatif, Kualitatif, dan $R \& D$ , Cet. VI; Bandung: Alfabeta, 2008.

Sahertian, A.Piet. Supervisi Pendidikan dalam Rangka Pengembangan Sumber Daya Manusia, Cet. I; Jakarta: RinekaCipta, 2001

Tim Dosen Administrasi Pendidikan Universitas Pendidikan Indonesia, Manajemen Pendidikan Bandung: Alfabeta, 2009

Tim Penyusun, Kamus Besar Bahasa Indonesia, Jakarta: Balai Pustaka, $2002 \quad$ Umaedi, manajemen Berbasis Sekolah, Jakarta: CEQM, 2004

Umiarso dan Imam Gojali, Manajemen Mutu Sekolah di Era Otonomi Pendidikan, Cet. II; Jogjakarta :Ircisod, 2011.

Ukas, Maman. Manajemen, Bandung: Agini, 2004.

Usman, Husaini. Manajemen: Teori, Praktik, dan Riset Pendidikan, Edisi Ketiga.Cet. I; Jakarta: Sinar Grafika Offset, 2009 
Uris, Auren. Buku Pedoman Eksekutif ,Yoyakarta: Yayasan Kanisius, 2000

Uwes,Sanusi. Visi dan Vondasi pendidikan dalam perspekti fislam Cet. I; Jakarta: logos, 2003
Wahjosumidjo,Kepemimpinan Kepala Sekolah; Tinjauan dan Permasalahannya Cet. I; Jakarta: Raja Grafindo persada, 2002.

Yahya, Ridwan. Memilih Pemimpin dalam Perspektif Islam, Jakarta: Pustaka Nawaitu, 2004 